\title{
THE EVALUATION OF ENTREPRENEUR INCUBATION PROGRAM AT HIGHER EDUCATION
}

\author{
Agus Suroso \\ Faculty of Economics and Business Jenderal Soedirman University, Purwokerto, Indonesia \\ Email: agus.suroso@unsoed.ac.id \\ Ascaryan Rafinda \\ Faculty of Economics and Business Jenderal Soedirman University, Purwokerto, Indonesia \\ University of Debrecen, Károly Ihrig Doctoral School of Management and Business, Hungary \\ Email: ascaryan.rafinda@yahoo.com

\section{Timea Gal} \\ University of Debrecen, Faculty of Economics and Business Institute of Marketing and Commerce, Hungary \\ Email: gal.timea@econ.unideb.hu
}

Received: 21 November 2020. Revision received: 7 December 2020. Accepted: 14 December 2020

\begin{abstract}
This research aims to identify the determinant factors of entrepreneurship in the case of university students. Internal and External factors are the focus of this research. We evaluate the perceived opportunity as an internal factor and facilities provided by the university as an external factor. The perceived opportunity is one factor that influences people's intention to establish a business the most. University facilities are an external factor in the most valuable help that university could provide for students to encourage them. This research also more in-depth evaluates student perception of business incubation programs in both universities. This research evaluated primary data from Jenderal Soedirman University, Indonesia, and Debrecen University, Hungary. Data was collected using a questionnaire. The results show that the perceived opportunity has a significant impact on the intention to establish a business. However, the business incubation program from campus does not affect student intention to establish a business. A more interesting finding is that Indonesian students have the lowest belief about the impact of business incubation programs compared to Hungarian and international students. This research's further implication is that the business incubation program needed to be improved to impact student willingness to establish a business significantly.
\end{abstract}

KEYWORDS: Business Incubation, Entrepreneurship, Cross-Country Study, Hungary, Indonesia.

JEL CLASSIFICATION: L26; M13; D91

Reference: Suroso, A., Rafinda, A \& Gal, T. (2020). The evaluation of entrepreneur incubation program at higher education. International Journal of Entrepreneurial Knowledge, 8(2), 14-26. doi: 10.37335/ijek.v8i2.113

\section{INTRODUCTION}

Someone choosing to become an entrepreneur usually has one of two possibilities, first, because of the necessity that forced them to establish a business, second, because they could catch the opportunities to open a business. At present, students continue their studies at the university expected to work for large and well-known companies. Rarely among those who have the desire to start their own business.

The entrepreneur has two critical roles in economic development. They contribute to the opening job opportunity and enhancing per capita income growth in their area. Entrepreneurial education also has an important role to economic development, creating job opportunities, and societal resilience (Lee et al., 2019). University as the highest formal education, should have a role in this issue. The importance of the entrepreneur in the country should be address by the university to provide sufficient education for the student. 


\section{INTERNATIONAL JOURNAL OF ENTREPRENEURIAL KNOWLEDGE}

Issue 2, volume 8, ISSN 2336-2960 (Online)

www.ijek.org

This research identifies two factors that could influence the student to become an entrepreneur. Internal and external factors can influence a person's decision to start a business. Various internal factors such as risk preferences, lifestyle, ability to read opportunities, readiness to face failure are found to have a role in decision making to start a business. At the same time, external factors such as economic shortages, family support, attitudes to money, and closest relationships are found to influence entrepreneurial behavior.

Entrepreneurship has been identified as of important thing since at least fifteenth century (Schumpeter et al., 2002). Several prior research on entrepreneurship intention using Theory of Planned Behavior model (Kautonen et al., 2015; Kolvereid, 1996; Krueger et al., 2000; Lüthje \& Franke, 2003; Schjoedt \& Shaver, 2012). This research will identify from a different aspect.

This research will identify the determinant factor that could increase students' opportunities to start a new business. Students who are studying at the university level have an academic environment. The academic environment is very different from the business environment, so that a facility from the campus is needed to train students in the business environment.

The importance of university support to the student that willing to establish a business is important (Kobylińska \& Lavios, 2020; Wright et al., 2017). The business incubation program is one of the promising concepts that provide university students to the business environment. The program provides the student with a different environment than the academic in university. The main idea is to coach the program and help the student address their interest in establishing a business. The university accompanies and helps the student when they need consultation and advice about their business.

This research identifies the determinant factor to establish a business that focuses on internal and external factors. The internal factor in this research focusing on the ability to see the business opportunity. The external factor in this research is support from the university which has a business incubation program at the university. The university support critical to evaluate as the previous researcher found that entrepreneurial education still inconclusive (Stverkova et al., 2018).

This research is in collaboration between Jenderal Soedirman University, Indonesia and the Debrecen University, Hungary. Both universities provide the student with a business incubation program for the student. They assist and provide students that need help to establish the business. The university help in providing knowledge, network and capital. At the University of Debrecen, there is a Team Academy. Team Academy facilitates students on campus by coaching and mentoring when they are interested in establishing a business and supporting them to join the investor pitching competition.

This research's first aim is to identify student perception of factors that determine starting a business in two variables. There is the ability to catch the opportunity and university support. This research's second aims are to evaluate how student perceived the university support to their intention to establish the business.

\section{THEORETICAL BASES}

\subsection{Perceived Opportunity}

The ability to understanding business opportunities is an important thing that can influence the decision to establish a business. Everyone may get the same information but have different reactions, people who can see "opportunities", they can change that information into a promising business. The ability to find and process the information is the key to start the business. 


\section{INTERNATIONAL JOURNAL OF ENTREPRENEURIAL KNOWLEDGE}

Issue 2, volume 8, ISSN 2336-2960 (Online)

www.ijek.org

Perception about business opportunities can automatically relate to the desire to open a new business. This ability becomes essential that can help someone become an entrepreneur (Vidal-Suñé \& LópezPanisello, 2013). This factor is the most important to be tested. This is because without knowing business opportunities, there is almost no possibility of someone starting a business. Then the first hypotheses is student perceived opportunity have a positive relation in intention to establish a business.

\subsection{University Facilities}

Most of the research on entrepreneurial intention focusing on individual personality and traits (Akinwale et al., 2019; Ali et al., 2019). However, there are external factor that could influence entrepreneurship intention. Factors such as government support, financial infrastructure, political willingness, human and technological factors could stimulate become successful entrepreneur (Ali et al., 2019; Maroufkhani et al., 2018). Opportunity from macro could be the first trigger for entrepreneurship (technology improvement), shifting of sociology (new perspective, new governance), organizational vision (new strategy), individual opinions (Henry et al., 2005). One of the critical aspects of entrepreneurship is an individual factor. The real project is one of the best ways to get entrepreneurial experience (Taatila, 2010). Several researchers agree that higher education have an important role to increase entrepreneurship (Tong et al., 2011; Zhang et al., 2014). Another researcher develops the entrepreneur orientation to use by the university department (Todorovic et al., 2011). Previous research on the impact of entrepreneur education is still mixed. The impact of entrepreneur education found positive relation to personal entrepreneurial intention (Anwar, Jamal, et al., 2020; Anwar, Saleem, et al., 2020; Thomas et al., 2014), while other researcher found the relation is negative (Oosterbeek et al., 2010).

Rarely previous research examines the impact of university facilities in student entrepreneurial intention. Previous research that identify role of university in entrepreneurial intention focus on university type and study major (Zhang et al., 2014). This research has different point of view from university role. This research identifies university facility for student that interest in establishing start-up. Previous research found that university support for student entrepreneurship program is an important factor that consider by student examine university quality (Çera et al., 2018). Support from the campus in the form of facilities that can be used by students becomes essential in this research. Campus facilities to support entrepreneurs such as business incubation, mentoring, and coaching could trigger the desire of students to become entrepreneurs. This research will identify the role of universities support in their intention to become entrepreneurs. The role of the university is seen from the provision of facilities that support students to experience the business environment.

The desire of someone to become an entrepreneur will be influenced by various factors. The difference between this research and various previous researches is that it focuses on internal factors such as perceived opportunity and external factors in the form of campus facilities. These two factors have never been tested in research on entrepreneurship. The second hypothesis proposed in this research is university facility could influence entrepreneurship intention.

\subsection{Entrepreneurial Intention}

Intention to become an entrepreneur is an important factor that have a significant role in individual decision to become entrepreneur (Ali et al., 2019; Arshad et al., 2019; Buli \& Yesuf, 2015; Liñán \& Fayolle, 2015). Entrepreneurial intention can be define as state of mind that directs attention, expertise and action into business (Bird, 1988). The recent definition explain that entrepreneur intention is the reflection of eagerness, willingness and passion to establish a new business (Buli \& Yesuf, 2015; Santos \& Liguori, 2019). It explain individual thoughts and actions as regards their willingness to establish a business. A person is said to have entrepreneurial intention when he already has the desire to start a business. This 
INTERNATIONAL JOURNAL OF ENTREPRENEURIAL KNOWLEDGE

Issue 2, volume 8, ISSN 2336-2960 (Online)

www.ijek.org

desire can be measured by direct questions about his desire for entrepreneurship. Here is the research model that was tested:

Figure 1 Research model

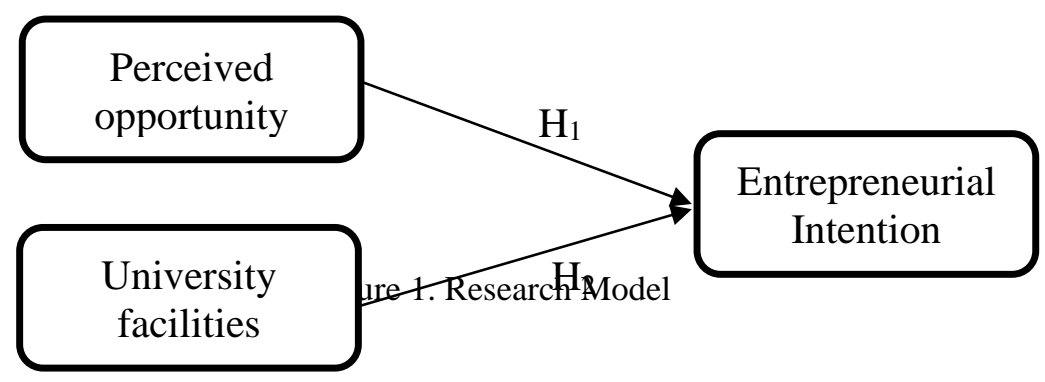

(Source: Authors own construction)

\section{METHODOLOGICAL BASES}

Hungarian, Indonesian and international student at university is the main purpose of this research target. This research used survey method. Data collection using convinience sampling. The link of the online questionnaire deployed through social media and chatting application. The offline questionnaire collected through colleague in both countries. The instrument of the research spread both online and offline. Data collection period is 30 working days from 10 May - 10 June 2020. The questionnaire translated into three language, there are Indonesian, Hungarian and English. Total 321 participant fill in the questionnaire. We only accept the questionnaire that fall in our criteria. The criteria are: 1 . Student active in the university, 2. Participating in the business incubation program (at the present or in the past), 3. Pass the positive and negative question check. Positive and negative question check is using to identify participant consistency in answering the questions. We make several question in both positive and negative wording and if participant is not consistent in both question, then we drop data.

Total 207 valid questionnaires collected. Total 207 participant from Indonesia, 54 Hungary student and 94 International student in Hungary as a valid sample in this research. The questionnaire using close ended question. Perceived opportunity measured using 3 questions, university facility 3 questions and entrepreneural Intention 2 questions.

Statistical tests conducted to answer the hypothesis in this study. Before identifying the relation between variable, validity and reliability test conducted to make sure the instrument is good to measure the construct. This research using confirmatory factor analysis to test the validity of the instrument. Then reliability test conducted to identify the reliability of the research instrument. Classical assumption test conducted before doing regression. To analyse the data, this research using simple linear regression. the data University facilities and perceived opportunity as independent variable and intention to start the business as dependent variable.

1.

\section{RESULT AND DISCUSSION}

Data collection was divided into three categories, namely Indonesian students, Hungarian students and international students in Hungary. Table 1 explain participants' demographics in this research. 
INTERNATIONAL JOURNAL OF ENTREPRENEURIAL KNOWLEDGE

Issue 2, volume 8, ISSN 2336-2960 (Online)

www.ijek.org

Table 1 describe that 58\% of the participant come from Indonesian, 15\% from Hungarian student and $26 \%$ from International student at Hungary. From total 354 valid participant in this research. Mostly of participant are single (93\%), married $(6 \%)$ and divorce $(1 \%)$. The youngest age is 18 years old and the oldest 43 years old.

Table 1 Demographic of the sample

\begin{tabular}{|c|c|c|c|c|}
\hline 2. & $\begin{array}{l}\text { Indonesian } \\
\text { student : } 207 \\
(58 \%)\end{array}$ & \begin{tabular}{l}
\multicolumn{1}{c}{ Sex } \\
Male : 59 \\
Female $: 147$ \\
Not disclose: 1
\end{tabular} & $\begin{array}{l}\text { Status } \\
\text { Single : } 202 \\
\text { Married : } 5 \\
\text { Divorce : } 0\end{array}$ & $\begin{array}{l}\quad \text { Age } \\
\text { Max: } 41 \\
\text { Min: } 18 \\
\text { Ave : } 22\end{array}$ \\
\hline 3. & $\begin{array}{l}\text { Hungarian } \\
\text { student : } 54 \\
(15 \%)\end{array}$ & $\begin{array}{l}\quad \text { Sex } \\
\text { Male }: 22 \\
\text { Female }: 32 \\
\text { Not disclose }: 0\end{array}$ & $\begin{array}{l}\text { Status } \\
\text { Single : } 43 \\
\text { Married : } 9 \\
\text { Divorce : } 1\end{array}$ & $\begin{array}{l}\text { Age } \\
\text { Max : } 42 \\
\text { Min : } 19 \\
\text { Ave : } 25\end{array}$ \\
\hline 4. & $\begin{array}{l}\text { International } \\
\text { student: } 94 \\
(26 \%)\end{array}$ & $\begin{array}{l}\quad \text { Sex } \\
\text { Male }: 47 \\
\text { Female }: 47 \\
\text { Not disclose }: 0\end{array}$ & $\begin{array}{l}\text { Status } \\
\text { Single : } 85 \\
\text { Married : } 9 \\
\text { Divorce : } 0\end{array}$ & $\begin{array}{r}\text { Age } \\
\text { Max : } 43 \\
\text { Min : } 18 \\
\text { Ave : } 24\end{array}$ \\
\hline
\end{tabular}

(Source: Authors own construction)

The result of validity and reliability test shows in the table 2 :

Table 2 Result of confirmatory factors analyses and reliability test

\begin{tabular}{lccc}
\hline \multicolumn{1}{c}{ Factors } & $\begin{array}{c}\text { Operational } \\
\text { Constructs }\end{array}$ & $\begin{array}{c}\text { Factor } \\
\text { Loading }\end{array}$ & $\begin{array}{c}\text { Cronbach } \\
\text { Alpha }\end{array}$ \\
\hline Perceived & PO1 & .901 & \\
Opportunity & PO2 & .879 & 0.898 \\
& PO3 & .921 & \\
University & UF1 & .800 & \\
Facilities & UF2 & .823 & 0.901 \\
Entrepreneurship & UF3 & .875 & \\
Intention & EI1 & .950 & 0.875 \\
\hline
\end{tabular}

(Source: Authors own construction)

Table 2 is summary of validity and reliability test of the instrument. From 8 questions that used in this research to set a research construct. The result from 8 questions classify into 3 variables. Each variable consists of 3 questions and 2 questions. Questions number 1 to 3 form the first variable, number 4 to 6 form the second variable and number 7 to 8 form the last variable. The decision was made based on the guideline for significant factor loading with the sample size minimum, with 354 sample the minimum factor loading can be used is 0,35 (Hair et al., 2019). This research using factor loading more than 0.800 as it shows on table 2 . The reliability test consider as very good if $\alpha \geq 0.90$, good if $\alpha \geq 0.80$ and satisfactory if $\alpha \geq 0.70$.

The results of this research identify the relationship between the ability to capture opportunities and university facilities against the intention to become entrepreneurs in Indonesia and Hungary. Conduct cross-country studies to find out comparisons between students in Indonesia, Hungary and International. More detailed discussion of the results of this research will be divided into three parts, namely: 1. Identify 


\section{INTERNATIONAL JOURNAL OF ENTREPRENEURIAL KNOWLEDGE}

Issue 2, volume 8, ISSN 2336-2960 (Online)

www.ijek.org

the relationships between variables from all research samples as a whole 2. Identify the differences in relations between these variables in populations from Indonesia, Hungary and internationally 3. Identify students' perceptions of the importance of campus facilities for the intention to become entrepreneurs from various countries.

\section{Test results for relationships between variables from all research samples}

The classic assumption test is carried out before testing the relationship between variables. The classic assumption test consists of a normality test, a multicollinearity test and a heterokedasticity test.

Normality test in this research uses the p-plots test. P-plots will show that the data is normally distributed when the research data is on a diagonal path on the p-plots graph. This research data shows that the data are normally distributed because the data is in the diagonal path of the p-plots graph. Multicollinearity test is accepted when tolerance value $>0,100$ and VIF value $<10.00$. The multicollinearity test results found that tolerance 0.216 in both independent variables and VIF 4.623 in both independent variables. From these two results it was concluded that this data had no symptoms of multicollinearity. Heterokedastity test in this research uses the Spearman test. Spearman test results indicate that there is a strong and positive relationship between the independent variables (the opportunity with the intention of 0.843 and the facility with the intention of 0.792 ) with the dependent. So there are no symptoms of heterokedasticity in this research data.

The results of the simple regression test found that the ability to read opportunities is a factor that affects a person's intention to become an entrepreneur because it has a sig value of 0,000 . The campus facility support factor was also found to have a significant effect on one's intention to become an entrepreneur because it had a sig value of 0,000 . This results shows that both first and second hypotheses found supported by this data. More details, this research conducting comparison analyses to find out the relationship between variable in certain group of sample (Indonesia, Hungary and International student) and identify student perception on incubation business program in university.

The test results of the relationship between variables from Indonesian, Hungarian and International students

The classic assumption test is carried out before testing the relationship between variables. The classic assumption test consists of a normality test, a multicollinearity test and a heteroscedasticity test. The classic assumption test using same exactly the previous analyses. The normality test using P-plot graph, the multicollinearity test using tolerance value and VIF value, the heteroscedasticity test using spearman test. Table 3 summary the result of the classical assumption test and simple regression test.

Table 3 Summary of classical assumption test and simple regression test

\begin{tabular}{|c|c|c|c|}
\hline & Assumption test & Regression test & Result \\
\hline Indonesian & $\begin{array}{l}\text { Normality: P-plot shows normal } \\
\text { No symptom of multicollinearity } \\
\text { No symptom of heteroscedasticity }\end{array}$ & $\begin{array}{l}\mathrm{H}_{1}: \operatorname{sig} \text { value: } \\
0.000 \\
\mathrm{H}_{2}: \text { sig value: } \\
0.064\end{array}$ & $\begin{array}{l}\mathrm{H}_{1} \text { : supported } \\
\mathrm{H}_{2} \text { : not supported }\end{array}$ \\
\hline Hungarian & $\begin{array}{l}\text { Normality: P-plot shows normal } \\
\text { No symptom of multicollinearity } \\
\text { No symptom of heteroscedasticity }\end{array}$ & $\begin{array}{l}\mathrm{H}_{1}: \text { sig value: } \\
0.888 \\
\mathrm{H}_{2}: \text { sig value: } \\
0.271\end{array}$ & $\begin{array}{l}\mathrm{H}_{1}: \text { not supported } \\
\mathrm{H}_{2} \text { : not supported }\end{array}$ \\
\hline International & $\begin{array}{l}\text { Normality: P-plot shows normal } \\
\text { No symptom of multicollinearity }\end{array}$ & $\begin{array}{l}\mathrm{H}_{1} \text { : sig value: } \\
0.001\end{array}$ & $\begin{array}{l}\mathrm{H}_{1} \text { : supported } \\
\mathrm{H}_{2}: \text { not supported }\end{array}$ \\
\hline
\end{tabular}


INTERNATIONAL JOURNAL OF ENTREPRENEURIAL KNOWLEDGE

Issue 2, volume 8, ISSN 2336-2960 (Online)

www.ijek.org

\begin{tabular}{|l|l|l|l|}
\hline & No symptom of heteroscedasticity & $\mathrm{H}_{2}$ : sig value: & \\
0.061 & & \\
\hline
\end{tabular}

(Source: Authors own construction)

The importance of university facility to enhance entrepreneurship intention

The next objective of this research is to evaluate university support for student business development. Two questions are given to student to understand this issue. There are: 1) Do you think that university support in business incubation has a good impact on student start-up-business? 2) Does university facilities motivate students to start their own business?.

The first question is conducted to find out students' perceptions of business coaching conducted by campus whether they think it will have a good impact or not. The second question is carried out to determine the impact of business coaching by the campus whether it will increase the likelihood of students implement their business idea.

Student perceptions will be analyzed by comparing the results of the two questions, by looking at how students' perceptions in each country on the question. The analysis was conducted using one-way ANOVA to find out the differences between one group and another. Comparisons are made between countries by comparing the value of each question asked.

\section{Student perceptions about the good impact of the business incubation program}

The first question is about students' perceptions about the impact of university support on their students' business. In this question, it will be seen whether students' perceptions that the business coaching program has a positive impact or not for students. One-way ANOVA group different test was conducted to see the differences in perception between students in Indonesia, Hungary and International. Following are the results of descriptive statistics regarding the good impact of the business incubation program:

Table 4 Descriptive statistics

\begin{tabular}{|l|c|c|c|c|c|c|c|c|}
\hline & \multirow{2}{*}{$\mathrm{N}$} & \multirow{2}{*}{ Mean } & \multirow{2}{*}{$\begin{array}{c}\text { Std. } \\
\text { Deviation }\end{array}$} & \multirow{2}{*}{$\begin{array}{c}\text { Std. } \\
\text { Error }\end{array}$} & & $\begin{array}{c}95 \% \text { Confidence Interval } \\
\text { for Mean }\end{array}$ & \multirow{2}{*}{ Minimum } & Maximum \\
\cline { 6 - 10 } & & & & & $\begin{array}{c}\text { Lower } \\
\text { Bound }\end{array}$ & $\begin{array}{c}\text { Upper } \\
\text { Bound }\end{array}$ & & \\
\hline Indonesia & 207 & 2,9614 & 1,42735 &, 09921 & 2,7658 & 3,1569 & 1,00 & 5,00 \\
\hline Hungarian & 54 & 3,9074 &, 95697 &, 13023 & 3,6462 & 4,1686 & 1,00 & 5,00 \\
\hline International & 94 & 3,7234 & 1,23048 &, 12691 & 3,4714 & 3,9754 & 1,00 & 5,00 \\
\hline Total & 355 & 3,3070 & 1,37526 &, 07299 & 3,1635 & 3,4506 & 1,00 & 5,00 \\
\hline
\end{tabular}

(Source: Authors own construction)

Table 4 is the result of descriptive statistics from students' perceptions about the impact of the campus business incubation program. The mean of the three student groups shows that Hungarian students have the highest level of trust (3.9074) in the business incubation program compared to international students (3.7234) and Indonesian students (2.9614). Hungarian students also have the smallest deviation (0.956) compared to international students (1.23) and Indonesian students (1.42).

\section{Table 5 Homogenity variance}

\begin{tabular}{|c|c|c|c|}
\hline Levene Statistic & df1 & df2 & Sig. \\
\hline 14,925 & 2 & 352 &, 000 \\
\hline
\end{tabular}


INTERNATIONAL JOURNAL OF ENTREPRENEURIAL KNOWLEDGE

Issue 2, volume 8, ISSN 2336-2960 (Online)

www.ijek.org

Table 6 shows that the anova test assumptions were not fulfilled. That is because the variance found in this research sample is different. Assumptions that are not fulfilled impact the ANOVA test results must use the unequal variance assume.

\section{Table 6 Robust Test of Equality of means}

\begin{tabular}{|c|c|c|c|c|}
\hline Kind of test & Statistic $^{\mathrm{a}}$ & df1 & df2 & Sig. \\
\hline Welch & 20,458 & 2 & 154,817 &, 000 \\
\hline Brown-Forsythe & 22,087 & 2 & 266,016 &, 000 \\
\hline
\end{tabular}
a. Asymptotically F distributed.

(Source: Authors own construction)

The results of the welch test and brown-for-the-test show that there are significant differences between groups in the research sample. The difference is not yet known between which sample groups. To find out the differences between groups, a post hoc analysis test is needed. This test is carried out to understand in more detail the differences in perceptions between groups. Post hoct analysis using assuming unequal variance is Games-Howell post hoc test.

Table 7 Post hoc analyses

\begin{tabular}{|c|c|c|c|c|c|c|c|}
\hline \multirow{2}{*}{ Kind of test } & \multirow{2}{*}{ (I) Country } & \multirow{2}{*}{ (J) Country } & \multirow{2}{*}{$\begin{array}{c}\text { Mean } \\
\text { Difference (I- } \\
\mathrm{J})\end{array}$} & \multirow{2}{*}{ Std. Error } & \multirow{2}{*}{ Sig. } & \multicolumn{2}{|c|}{$\begin{array}{c}95 \% \text { Confidence } \\
\text { Interval }\end{array}$} \\
\hline & & & & & & $\begin{array}{l}\text { Lower } \\
\text { Bound }\end{array}$ & $\begin{array}{l}\text { Upper } \\
\text { Bound }\end{array}$ \\
\hline \multirow{6}{*}{ Games-Howell } & \multirow{2}{*}{ Indonesia } & Hungary &,$- 94605^{*}$ & ,16371 & 000 & $-1,3345$ &,- 5576 \\
\hline & & International &,$- 76205^{*}$ & 16109 & , 000 & $-1,1423$ &,- 3818 \\
\hline & \multirow{2}{*}{ Hungary } & Indonesia & ,94605* & ,16371 & 000 & ,5576 & 1,3345 \\
\hline & & International & , 18400 & ,18184 &, 571 &,- 2470 & ,6150 \\
\hline & \multirow{2}{*}{ International } & Indonesia &, $76205^{*}$ & ,16109 &, 000 & ,3818 & 1,1423 \\
\hline & & Hungary &,- 18400 & ,18184 & ,571 &,- 6150 & 2470 \\
\hline
\end{tabular}

*. The mean difference is significant at the 0.05 level.

(Source: Authors own construction)

Table 7 shows the results of the post hoc analysis using games-howell. These results indicate that there are differences in perception between Indonesian students with hungarian and international students. But no significant differences were found between Hungarian students and international students.

Students' perceptions about the impact of the business incubation program on the motivation of starting a student business

The second question will find out students' perceptions about the role of business incubation in the spirit of building a business. The analysis will look at differences in perceptions between students in Indonesia, Hungary and international students of this perception. The results of descriptive statistics regarding this question are presented in Table 8.

Before conducting the ANOVA difference test, a homogeneity of variance assumption is tested. The results of the homogeneity of variance test of this second question were found to be significant. This means that the variance of this group is different. So it does not qualify for anova test. Then welch and Brown-Forsythe test could be conducted to examine the difference between group. 
INTERNATIONAL JOURNAL OF ENTREPRENEURIAL KNOWLEDGE

Issue 2, volume 8, ISSN 2336-2960 (Online)

www.ijek.org

Table 8 Descriptive statistics result

\begin{tabular}{|c|c|c|c|c|c|c|c|c|}
\hline & \multirow[t]{2}{*}{$\mathrm{N}$} & \multirow[t]{2}{*}{ Mean } & \multirow[t]{2}{*}{$\begin{array}{c}\text { Std. } \\
\text { Deviation }\end{array}$} & \multirow[t]{2}{*}{ Std. Error } & \multicolumn{2}{|c|}{$\begin{array}{c}95 \% \text { Confidence Interval } \\
\text { for Mean }\end{array}$} & Minimum & Maximum \\
\hline & & & & & $\begin{array}{l}\text { Lower } \\
\text { Bound }\end{array}$ & Upper Bound & & \\
\hline Indonesia & 207 & 3,0531 & 1,41493 & ,09834 & 2,8592 & 3,2470 & 1,00 & 5,00 \\
\hline Hungary & 54 & 3,8889 &, 94503 & ,12860 & 3,6309 & 4,1468 & 2,00 & 5,00 \\
\hline International & 94 & 3,8085 & 1,22058 & ,12589 & 3,5585 & 4,0585 & 1,00 & 5,00 \\
\hline Total & 355 & 3,3803 & 1,35678 & 07201 & 3,2387 & 3,5219 & 1,00 & 5,00 \\
\hline
\end{tabular}

(Source: Authors own construction)

Table 9 Robust Test of Equality of means

\begin{tabular}{|l|r|r|c|r|}
\hline & \multicolumn{1}{|c|}{ Statistic $^{\mathrm{a}}$} & \multicolumn{1}{|c|}{ df1 } & df2 & \multicolumn{1}{c|}{ Sig. } \\
\hline Welch & 17,799 & 2 & 155,060 &, 000 \\
Brown-Forsythe & 19,857 & 2 & 266,449 &, 000 \\
\hline
\end{tabular}

a. Asymptotically F distributed.

(Source: Authors own construction)

The results of the welch test and brown-for-the-test show that there are significant differences between groups in the research sample. The difference is not yet known between which sample groups. To find out the differences between groups, a post hoc analysis test is needed. This test is carried out to understand in more detail the differences in perceptions between groups. Post hoct analysis using assuming unequal variance is Games-Howell post hoc test.

\section{Table 1 Result of posthoc test}

\begin{tabular}{|c|c|c|c|c|c|c|c|}
\hline \multicolumn{8}{|c|}{ Multiple Comparisons } \\
\hline \multicolumn{8}{|c|}{ Dependent Variable: ScoreX2 } \\
\hline & (I) Country & (J) Country & Mean & Std. Error & Sig. & \multicolumn{2}{|c|}{ 95\% Confidence Interval } \\
\hline & & & $\begin{array}{l}\text { Difference } \\
(I-J)\end{array}$ & & & Lower Bound & Upper Bound \\
\hline \multirow{6}{*}{ Games-Howell } & \multirow{2}{*}{ Indonesia } & Hungary &,$- 83575^{*}$ & , 16190 &, 000 & $-1,2199$ &,- 4516 \\
\hline & & International &,$- 75537^{*}$ & , 15975 &, 000 & $-1,1325$ &,- 3782 \\
\hline & \multirow{2}{*}{ Hungary } & Indonesia &, $83575^{*}$ & , 16190 &, 000 &, 4516 & 1,2199 \\
\hline & & International & ,08038 & , 17997 & ,896 &,- 3462 & ,5069 \\
\hline & \multirow{2}{*}{ International } & Indonesia & , $75537^{*}$ & , 15975 &, 000 & ,3782 & 1,1325 \\
\hline & & Hungary &,- 08038 & ,17997 & 896 &,- 5069 & ,3462 \\
\hline
\end{tabular}

(Source: Authors own construction)

Table 9 shows the results of post hoc analysis using games-howell. These results indicate that there are differences in perception between Indonesian students with hungarian and international students. But no significant differences were found between Hungarian students and international students. From table 7 , 8 and 9 we can see that Indonesian student has the smallest score on this question compare to Hungary and international student.

\section{CONCLUSION}

The results of this research found that students perceiving the ability to read opportunities had a significant effect on opening a business. This finding the second result is discussing the effect of the 


\section{INTERNATIONAL JOURNAL OF ENTREPRENEURIAL KNOWLEDGE}

Issue 2, volume 8, ISSN 2336-2960 (Online)

www.ijek.org

business incubation program on campus. Students perceive that the business incubation program does not significantly affect students' intention to establish a business. The third result is the evaluation of the business incubation program from a student point of view. In the third result, we found that the Indonesian student has the least belief in the program's impact compared to another group of students.

In more detail, this research compares the perceptions of students in Indonesia, Hungary, and internationally in seeing the business incubation program on their campus. The different test shows that Indonesian students have the lowest student perception business incubation program on their campus compared to others. At the same time, there were no differences between international students and Hungarian students in their perception of the business incubation program.

This research indicates that the role of business incubation facilities from the campus has not been effectively felt by students in all samples, both in Hungary and in Indonesia. This finding support previous research that the relationship is not positive (Oosterbeek et al., 2010). But judging from the level of student perception, students in Hungary (Hungarian students and international students) have higher trust than students in Indonesia regarding the business incubation program's impact. Students in Hungary have a higher level of confidence that business incubation and coaching programs from campus positively impact their business. This indicates that students in Hungary are more confident in the business incubation program owned by their campus than students in Indonesia.

The limitation of this research is only comparing two countries. It would be more interesting to compare to other countries that the university has an entrepreneur education program. Then each country would get benefit from learning from other programs. It would be more interesting if the study could cover different points of view from students and lecturers or business owners about the business incubation program.

This research implies that there must be an evaluation of a business incubation program conducted at the university to find out why students do not perceive a business incubation program as a program that has a good impact on these students. It can be further explored why business incubation programs in Hungary, especially at the University of Debrecen, can be more trusted by students to impact their business. Future research plans will be interesting to know about business incubation programs conducted at both universities in Indonesia and Hungary. The incubation program will be interesting to know and discuss how the business incubation program between the two universities is compared.

\section{Acknowledgments}

The publication of this study was supported by funding from Research and Public Service Institute Universitas Jenderal Soedirman Indonesia under the Professor Facilitation Grant Program 2020 number 123/UN.23.18/PT.01.05/2020.

\section{REFERENCES}

Akinwale, Y. ., Ababtain, A. ., \& Alaraifi, A. A. (2019). Structural equation model analysis of factors influencing entrepreneurial interest among university students in Saudi Arabia. Journal of Entrepreneurship Education, 22(4), 1-14.

Ali, I., Ali, M., \& Badghish, S. (2019). Symmetric and asymmetric modeling of entrepreneurial ecosystem in developing entrepreneurial intentions among female university students in saudi arabia. International Journal of Gender and Entrepreneurship, 11(4), 435-458.

Anwar, I., Jamal, T. ., Saleem, I., \& Thoudam, P. (2020). Traits and entrepreneurial intention: testing the 


\section{INTERNATIONAL JOURNAL OF ENTREPRENEURIAL KNOWLEDGE}

Issue 2, volume 8, ISSN 2336-2960 (Online)

www.ijek.org

mediating role of entrepreneurial attitude and self-efficacy. Journal for International Business and Entrepreneurship Development.

Anwar, I., Saleem, I., Thoudam, P., Islam, K. M. ., \& Khan, R. (2020). Entrepreneurial intention among female university students: examining the moderating role of entrepreneurial education. Journal for International Business and Entrepreneurship Development. https://www.inderscience.com/info/ingeneral/forthcoming.php?jcode5jibed.

Arshad, M., Farooq, O., \& Farooq, M. (2019). The effect of intrinsic and extrinsic factors on entrepreneurial intentions: The moderating role of collectivist orientation. Management Decision, 57(3), 649-668.

Bird, B. (1988). Implementing Entrepreneurial Ideas: The Case for Intention. Academy of Management Review, 13(3), 442-453. https://doi.org/10.5465/AMR.1988.4306970

Buli, B. ., \& Yesuf, W. . (2015). Determinants of entrepreneurial intentions: Technical-vocational education and training students in ethiopia. Education \& Training, 57, 891-907.

Çera, G., Cepel, M., Zakutna, S., \& Rozsa, Z. (2018). Gender differences in perception of the university education quality as applied to entrepreneurial intention. Journal of International Studies, 11(3), 147160. https://doi.org/10.14254/2071-8330.2018/11-3/13

Hair, J. F., Black, W. C., Babin, B. J., \& Anderson, R. E. (2019). Multivariate Data Analysis : Multivariate Data Analysis.

Henry, C., Hill, F., \& Leitch, C. (2005). Entrepreneurship education and training: Can entrepreneurship be taught? Part I. Education and Training, 47(2), 98-111. https://doi.org/10.1108/00400910510586524

Kautonen, T., van Gelderen, M., \& Fink, M. (2015). Robustness of the theory of planned behavior in predicting entrepreneurial intentions and actions. Entrepreneurship: Theory and Practice, 39(3), 655-674. https://doi.org/10.1111/etap.12056

Kobylińska, U., \& Lavios, J. J. (2020). Development of research on the university entrepreneurship ecosystem: Trends and areas of interest of researchers based on a systematic review of literature. Oeconomia Copernicana, 11(1), 117-133. https://doi.org/10.24136/oc.2020.005

Kolvereid, L. (1996). Prediction of Employment Status Choice Intentions. Entrepreneurship Theory and Practice, 21(1), 47-58. https://doi.org/10.1177/104225879602100104

Krueger, N. F., Reilly, M. D., \& Carsrud, A. L. (2000). Competing models of entrepreneurial intentions. Journal of Business Venturing, 15(5), 411-432. https:/ / doi.org/10.1016/S0883-9026(98)00033-0

Lee, H., Ahmed, U., Zhussupova, B., \& Khalid, N. (2019). Impact of innovation capability and competitiveness on entrepreneurial orientation regarding to the entrepreneurial education in business performance among south Korean firms. Polish Journal of Management Studies, 20(2), 358367. https://doi.org/10.17512/pjms.2019.20.2.30

Liñán, F., \& Fayolle, A. (2015). A systematic literature review on entrepreneurial intentions: Citation, thematic analyses, and research agenda. International Entrepreneurship and Management Journal, 11(4), 907-933.

Lüthje, C., \& Franke, N. (2003). The "making" of an entrepreneur: Testing a model of entrepreneurial intent among engineering students at MIT. $\mathrm{R}$ and $D$ Management, 33(2), 135-147. https://doi.org/10.1111/1467-9310.00288

Maroufkhani, P., Wagner, R., \& Wan Ismail, W. K. (2018). Entrepreneurial ecosystems: A systematic review. Journal of Enterprising Communities: People and Places in the Global Economy, 12(4), 545-564.

Oosterbeek, H., Van Praag, M., \& Ijsselstein, A. (2010). The impact of entrepreneurship education on entrepreneurship skills and motivation. European Economic Review, 54(3), 442-454.

Santos, S. ., \& Liguori, E. . (2019). Entrepreneurial self-efficacy and intentions: Outcome expectations as mediator and subjective norms as moderator. International Journal of Entrepreneurial Behaviour \&Research, 26(3), 400-415.

Schjoedt, L., \& Shaver, K. G. (2012). Development and validation of a locus of control scale for the entrepreneurship domain. Small Business Economics, 39(3), 713-726. https://doi.org/10.1007/s11187-011-9357-0 
INTERNATIONAL JOURNAL OF ENTREPRENEURIAL KNOWLEDGE

Issue 2, volume 8, ISSN 2336-2960 (Online)

www.ijek.org

Schumpeter, J., Becker, M. C., \& Knudsen, T. (2002). New Translations : Theorie der wirtschaftlichen Entwicklung. THe American Journal of Economics and Sociology2, 61(2), 405-437.

Stverkova, H., Pohludka, M., Kurowska-Pysz, J., \& Szczepańska-Woszczyna, K. (2018). Cross-border enterprepreneurship in euroregion beskydy. Polish Journal of Management Studies, 18(2), 324-337. https://doi.org/10.17512/pjms.2018.18.2.26

Taatila, V. P. (2010). Learning entrepreneurship in higher education. Education and Training, 52(1), 48-61. https://doi.org/10.1108/00400911011017672

Thomas, A., Passaro, R., \& Scandurra, G. (2014). The perception of the contextual factors as predictor of entrepreneurial intent: evidences from an empirical survey. Journal of Enterprising Culture, 22(4), 375-400.

Todorovic, Z. W., McNaughton, R. B., \& Guild, P. (2011). ENTRE-U: An entrepreneurial orientation $\begin{array}{llll}\text { scale for } \quad \text { universities. } & \text { 128-137. }\end{array}$ https://doi.org/10.1016/j.technovation.2010.10.009

Tong, X. ., Tong, D. Y. ., \& Loy, L. . (2011). Factors influencing entrepreneurial intention among university studet. International Journal of Social Science and Humanity Studies, 3(1), 487-496.

Vidal-Suñé, A., \& López-Panisello, M. B. (2013). Determinantes institucionales y económicos de la percepción de oportunidades y de la intención emprendedora. Investigaciones Regionales, 26(26), 75 96.

Wright, M., Siegel, D. S., \& Mustar, P. (2017). An emerging ecosystem for student start-ups. Journal of Technology Transfer, 42(4), 909-922. https://doi.org/10.1007/s10961-017-9558-z

Zhang, Y., Duysters, G., \& Cloodt, M. (2014). The role of entrepreneurship education as a predictor of university students' entrepreneurial intention. International Entrepreneurship and Management Journal, 10(3), 623-641. https://doi.org/10.1007/s11365-012-0246-z

Xiao, J. J., Tang, C., Serido, J., \& Shim, S. (2011). Antecedents and Consequences of Risky Credit Behavior Among College Students: Application and Extension of the Theory of Planned Behavior. Journal of Public Policy \& Marketing, 30(2), 239-245. https://doi.org/10.1509/jppm.30.2.239

Zhang, Y., Duysters, G., \& Cloodt, M. (2014). The role of entrepreneurship education as a predictor of university students' entrepreneurial intention. International entrepreneurship and management journal, 10(3), 623-641.

\section{BRIEF DESCRIPTION OF AUTHOR/AUTHORS:}

\section{Prof. Dr. Agus Suroso, MS}

Department of Management, Faculty of Economics and Business, Jenderal Soedirman University, Jl. H.R Boenyamin no. 708, Purwokerto, Indonesia. Affiliation website: feb.unsoed.ac.id. agus.suroso@unsoed.ac.id. Current position: Head of PhD Program in management and business Jenderal Soedirman University. Main research interest: Marketing, strategic, entrepreneur, and rural development.

\section{Ascaryan Rafinda, M.Sc}

Department of Accounting, Faculty of Economics and Business, Jenderal Soedirman University, Jl. H.R Boenyamin no. 708, Purwokerto, Indonesia and PhD Student University of Debrecen, Hungary. Affiliation website: feb.unsoed.ac.id / unideb.hu. email: ascaryan.rafinda@unsoed.ac.id; ascaryan.rafinda@econ.unideb.hu; ascaryan.rafinda@yahoo.com. Current position: PhD student at the University of Debrecen Hungary. Main research interest: Behavioral Finance, Financial Education, Entrepreneurship.

\section{Dr. habil. Timea Gal, PhD}


INTERNATIONAL JOURNAL OF ENTREPRENEURIAL KNOWLEDGE

Issue 2, volume 8, ISSN 2336-2960 (Online)

www.ijek.org

Department of Marketing, Faculty of Economics, Debrecen University, Hungary, Bosormenyi ut, Debrecen, Hungary, unideb.hu, gal.timea@econ.unideb.hu. Main research interest: Entrepreneurship, Teaching method, Marketing. 